\title{
Controlling Spread of the Oak Wilt Pathogen (Ceratocystis fagacearum) in a Minnesota Urban Forest Park Reserve
}

\author{
Jennifer Juzwik, Joseph O’Brien, Charles Evenson, Paul Castillo, and Graham Mahal
}

\begin{abstract}
Effectiveness of oak wilt control actions taken between 1997 and 1999 were evaluated for an urban forest park reserve in Minnesota, U.S. A high level of success ( $84 \%$ of evaluated disease centers) was achieved in controlling belowground spread of the vascular pathogen for four to six years by mechanically disrupting inter-tree root connections with the blade of a cable plow (vibratory plow, VP). Placements of the outermost (i.e., primary) VP treatment lines were based on a modified, rule-of-thumb model. Plausible scenarios based on two protocols for preventing pathogen spore production, and thus aboveground insect-mediated spread, were explored in conjunction with alternative, root treatment models using a geographical information system. For the $95 \%$ confidence level of a statistical model, the numbers of red oaks inside primary lines were 2.5 times greater than those inside the primary, installed lines and represents the difference in tree losses if all red oaks were removed to the primary lines [i.e., a "cut-to-the-line" (CTL) protocol]. Alternatively, a "monitor and remove" (MR) option (i.e., annual removal of wilting red oaks), would have resulted in $64 \%$ fewer removals than CTL. The park's forestry division subsequently added the MR protocol to its oak wilt control program. Key Words: Cultural Control; Insect Vector Spread; Integrated Pest Management; Plant Health Care.
\end{abstract}

Oak wilt, caused by the fungus Ceratocystis fagacearum (Bretz) Hunt, has been considered the forest disease of greatest concern in four of the twenty-three U.S. states in which it occurs (Billings 2000). It is estimated that tens of thousands of oaks are killed annually in the north central United States. In Anoka County, Minnesota, U.S., 990 active infection centers were documented in 2008; however, no estimates of tree mortality were given (Haight et al. 2009).

Operational management of oak wilt in portions of states with organized disease suppression programs includes tools or activities that disrupt or prevent the spread of the pathogen from diseased to healthy trees. In Minnesota, belowground or root-graft spread is commonly controlled through the use of a vibratory plow equipped with a $152 \mathrm{~cm}$ long blade that mechanically severs roots and, thus, breaks root connections between oaks joined by root grafts. Different models exist for directing the placement of the vibratory plow lines (VPLs) (French and Stienstra 1978; Bruhn et al. 1991). A modified version of the model developed by French and Stienstra (1978) is most widely used in Minnesota. In general, root grafting frequency is highest between individuals of the same species and lower between different oak species. Root grafting between a red oak (Section Lobatae, Subgenus Quercus) and a white oak species tree (Section Quercus, Subgenus Quercus) occurs infrequently to rarely (Juzwik 2009). Other factors within a stand that affect grafting and the frequency of pathogen spread frequency include basal area of oaks, topographic relief, soil depth, soil texture, and occurrence of non-oak species (Bruhn and Heyd 1992; Juzwik 2009).

Aboveground spread of $C$. fagacearum in Minnesota occurs when a sap beetle vector (Coleoptera: Nitidulidae) visits a fresh, xylem-penetrating wound on a healthy oak after acqui- sition of the oak wilt fungus from sporulation mats formed on oaks that died from oak wilt the previous growing season (Juzwik et al. 2004b). Sporulation is most common on red oak species, less common on bur oak, and insignificant on white oak. The primary strategies used to control insect spread of oak wilt in Minnesota are 1) avoidance of wounding during the critical spring period (e.g., not pruning or harvesting oaks unless the exposed xylem is immediately covered by paint), and 2) elimination of inoculum by removing all potential spore mat producing trees (PSPTs) before mats form. At least two different options have been used in Minnesota to implement the second strategy. "Monitor and remove" involves annual inspection and subsequent removal of any wilting red oaks inside the outermost VPLs (USDA Forest Service, NA S\&PF 2009). A modification of this option involves removal of a red oak only if its cambial condition indicates sporulation is likely to occur (Cook 2001). The "cut-to-the-line" option involves removal of all red oaks within the outermost VPLs within the same year of vibratory plow treatment (USDA Forest Service, NA S\&PF 2009).

The oak wilt control program for Murphy-Hanrehan Park Reserve (4442'34”N; 9320'08'W), northeastern Scott County, $\mathrm{MN}$, was initiated in 1978 and is administered through the forestry division of the Three Rivers Park District. This program represents one of the longest-running, continuous oak wilt suppression efforts in the state. The 2,400 acre reserve is undeveloped and largely forested land managed for recreation, species diversity, wildlife habitat, and the preservation of existing forest vegetation in the larger Minneapolis-St. Paul metropolitan area. Privately-owned, suburban properties populate the park boundaries, particularly on the northern and eastern edges. Northern red oak (Quercus rubra), bur oak ( $Q$. macrocarpa), and white oak ( $Q . a l b a)$ are the predom- 
inant species in the forested areas. Other tree species present include American elm, hackberry, red maple, and trembling aspen.

Oak wilt is a major disease affecting oaks in the reserve. Mortality of 57 red and bur oaks was documented in 2008 (C. Evenson, unpublished data). Park staff believe annual mortality would be much greater if not for the long-term operational control efforts. Oak wilt is also common in forested lots bordering the park lands, but uniform control efforts are lacking in these areas. The objectives of the park's oak wilt control program are to preserve as many oaks as possible while reducing probability of pathogen spread to a low level. In general, eradication of oak wilt from the park is not considered achievable largely due to the inability to control pathogen spread from bordering private lands.

The primary tools or activities used to control oak wilt in the park have been aerial and ground surveys for detecting and monitoring the disease, the vibratory plow to disrupt belowground spread of the fungus in established infection centers, and avoidance of wounding during spring months when risk of aboveground spread is highest. The park staff maintains detailed records of annual occurrence of wilt in existing and new infection centers, potential for oak wilt spore mat occurrence on wilted oaks, and of vibratory plow lines established each year. These records as well as annual assessments of the status of infection centers are used to evaluate the effectiveness of vibratory plow lines in controlling belowground pathogen spread and the need for re-treatment. A more formal, but unpublished, evaluation of VPL effectiveness in the park was conducted in 1988 (D. Shelstad, pers. comm.; copy on file with USDA Forest Service). Based on evaluation of ten vibratory plow-treated oak wilt sites per year between 1978 and 1982, treatments failed to contain the fungus on $30 \%$ to $40 \%$ of the sites four years after plowing on each site. However, the lines were established using a vibratory plow with a $122 \mathrm{~cm}$ long blade as this was before the availability of the current $152 \mathrm{~cm}$ long blade.

This paper focuses on an evaluation of oak wilt control activities in the park reserve between 1997 and 2006 and the results of spatial analyses used to consider adoption of new and/or refined control measures to the park's program. The goal of the latter was to consider ways to improve vibratory plow effectiveness and additional measures designed to reduce probability of aboveground pathogen spread by insect vectors. The specific objectives of this evaluation were to 1) determine the success rate of VPLs in preventing oak wilt spread beyond the established disease center over a six to eight-year period, and 2) using a geographical information system, a) compare actual VPL placement to hypothetical line placement had a different model been used, and b) compare numbers of oaks that would have been removed within outermost VPLs under different disease sanitation scenarios designed to reduce pathogen inoculum availability for insect spread.

\section{MATERIALS AND METHODS}

\section{Study Area and Site Descriptions}

Field data used in this analysis were collected from actively managed oak wilt infection centers in Murphy-Hanrehan Park Reserve. The area is characterized by glacial ridges and hilly terrain occurring on glacial moraines. The mixed hardwood forests of the reserve lie within the Big Woods ecological subsection of the Minneapolis-St. Paul metropolitan area (Keys et al. 1995; Minnesota DNR 2006). Twenty-five active oak wilt centers in which
VPLs had been installed between 1997 and 1999 were selected for this study. The criteria for selection of a study site stipulated that the candidate center was not coalescing with an adjacent center and the center had only been treated one time for oak wilt, i.e. had not and would not be re-treated with the vibratory plow during the study time period. Detailed site records, maps of VPL placement, and electronic geographic information system (GIS) files collected by park staff were available for use in the study. Soils in each of the VPL treatment sites were classified in one of the following: Kingsley, Mahtomedi and Hayden soil series complex; Kingsley-Mahtomedi complex; Hayden loam; and Hayden sandy loam arising from glacial till or outwash/till soil parent material (USDA NRCS 2007). Moderate slopes (15\% to $25 \%$ ) were characteristic of most (21) of the disease sites. The estimated densities of red oaks in the sites ranged from 30 to 178 stems per acre. The average diameter of red oak stems in treatment sites ranged from 23 to $51 \mathrm{~cm}$ at $1.4 \mathrm{~m}$ height (dbh). White oak presence on the sites varied from two sites where the white oaks out-numbered the red oaks to three sites where red oaks were ten times more numerous than the white oaks.

\section{Vibratory Plow Line Treatment}

The park forester marked lines for VPL treatment using a modification of a model initially developed by French and Stienstra (1978). The outermost lines established, called primary lines, are those considered highly likely to arrest belowground spread of the pathogen outside the existing disease center. Lines established within the primary line, called secondary lines, were placed between the wilting tree(s) and the primary VPL, usually just beyond the last wilting tree or one tier of healthy trees toward the primary line. On most sites, both primary and secondary lines were marked. A tracked cable plow (Ditch Witch HT-100, The Charles Machine Works, Inc., Perry, OK) or an articulated-steering, rubber-tired cable plow (Vermeer Corp., Pella, IA), both with a vibrating unit operating a $152 \mathrm{~cm}$ blade, was used to sever any connected roots. The tracked plow was preferred in the study area due to its superior ability to climb and maneuver on the steep slopes present in the park. However, this machine was not available for use in 1999. The plow blade was inserted into the ground to the maximum operating depth and pulled through soil along flagged lines. The plowing on the sites was performed between late August and early November during 1997, 1998, and 1999. The field crews documented VPL placement by tagging the base of "witness" trees that were generally on the outside of the plowed lines.

\section{Site Mapping}

Field site and tree data were collected to enable mapping of all oak trees (dead or alive) on each study site. The data were collected between July and mid-September 2001. In general, the plot center was near the original, diseased oak or within the cluster of originally infected trees. Coordinates for the plot center were obtained using a geographical positioning system (GPS) with sub-meter accuracy (Ashtech BR2G GPS/Beacon Receiver, Magellan Corp., Santa Clara, CA). A portable field computer (Ranger 133R, Tripod Data Systems, Corvallis, OR) connected to a digital compass (Laser Technology Map Star Compass, Module I, Centennial, CO) and a laser range finder (Laser Technology Impulse 200 Laser Range Finder, Centennial, $\mathrm{CO}$ ) was used to collect spatial location data for each oak 
within the primary VPL and up to $15 \mathrm{~m}$ beyond or as the situation required. An inventory of all the mapped oak stems was taken and recorded electronically. Species, stem diameter(s), and tree condition (e.g., live, no oak wilt; currently wilting, dead due to oak wilt; dead due to other causes), were noted for each tree. Locations and diameters of oak stumps were recorded when present. Coordinate data, location data for each oak stem in relation to the plot center (i.e., azimuth and distance), and tree data were imported into a GIS (ArcView 8.03, Redlands, CA) and stem maps were created for each site.

\section{Other Data Collection}

\section{Wilting tree data}

Location, species and size of each wilting oak detected was recorded by park staff during ground disease surveys conducted between July and late-August of each year between 1997 and 2005. GPS coordinates for each wilting tree were used to create modified stem maps for each site with tree condition status for each year between the treatment year and 2005.

\section{VPL location data}

Using a handheld GPS, park staff recorded locations of all plow lines installed in the 25 sites. These line data were imported into the GIS project as a VPL layer for each site. Supplemental location data (GPS obtained coordinates) for witness trees were also imported and used to adjust line placement when each stem map was overlaid with the VPL layer. Hand drawn maps and tree maps created prior to VPL treatment were also used to adjust line placements in the GIS. Ground checking was also conducted in summer 2006 for twelve sites where questions about line placement remained. Final VPL placement for each site was then used to create annual site maps containing all oak stems and their conditions between 2001 and 2005. Length of the primary and secondary lines installed on each site were measured in the GIS and compared with estimated line length on the original field data sheets as recorded by the park forestry technician.

\section{Evaluation of VPL Effectiveness}

The location of wilting trees in relation to installed primary and secondary VPLs on each site map were examined to determine whether the disease had spread beyond the VPLs each year between 2001 and 2005. Knowledge of separate oak wilt infection centers developing in the vicinity of the treated centers was also used to determine whether wilting trees appearing outside the VPLs were likely to be from an encroaching center, due to overland spread of the fungal pathogen by insect vectors, or attributable to failure of the installed VPLs to contain the original infection(s). The resulting determination was recorded for both secondary and primary VPLs in each site. The overall success or failure rate of plow treatment was based on number of sites where primary lines apparently failed to contain the disease per total number of centers treated. The year of apparent failure was also noted.

\section{Comparison of Potential Spore Producing Tree Sanitation Options}

During the years of the study, the park reserve did not employ either a "cut-to-the-line" or a "monitor and remove" strategy to reduce potential spore mat producing trees; thus, no red oaks were identified and removed in the 25 sites during the course of this study. However, the number of potential PSPTs that arose each year could be estimated using the stem maps and the GIS. To obtain estimates of trees that would have been removed had the "cutto-the-line" option been implemented by the park, the number of all live red oaks within the primary lines on each site in the year of plow treatment were tallied. The cumulative number of red oaks that wilted on each site during the study period was used to estimate hypothetical removal under a "monitor and remove" scenario.

\section{Comparison of VPL Placement Models}

Hypothetical, model-placed VPLs based on the Pemene soils equation (Equation 1) of the statistical model developed by Bruhn et al. (1991) were evaluated. Specifically, two lines representing the $95 \%$ and the $80 \%$ confidence level were created in a GIS layer of theoretical VPLs for each site.

[Equation 1] $\quad \mathrm{D}=(\mathrm{dtt}+\mathrm{dst}) / \mathrm{e}^{(\mathrm{l}-\mathrm{Z}-[0.5659735 *(\text { Soil) })] / 2.481853)}$

where $\mathrm{D}=$ inter-tree distance (feet) associated with $95 \%$ or $80 \%$ probabilities that a tree will not contract oak wilt through root grafts from an inoculum source tree for one year following its death; $\mathrm{dtt}=$ diameter of healthy tree; $\mathrm{dst}=$ diameter of inoculum source tree; $\mathrm{Z}=$ a variable based on the level of confidence desired $(=1.645$ for $95 \%$ confidence level and 0.842 for $80 \%$ confidence level); and Soil = 1 for Pemene soils.

Because a $3 \mathrm{~m}$ width clearance is required for plow operation, these modeled lines were adjusted to account for such practical considerations. Hypothetical red oak removals under a "cut-to-the-line" scenario and a hypothetical "monitor and remove" scenario were then estimated and compared for the two modeled VPLs (at two different confidence levels) and the installed VPLs for each site using the GIS.

\section{RESULTS}

\section{Characteristics of Installed VPLs}

For the ten active oak wilt sites treated in 1997, only primary VPLs were established in two, while both primary and secondary VPLs were placed in the remaining sites (Table 1). Both types of VPLs were established in the nine sites treated with the plow in 1998 and the six sites treated in 1999. Length of barriers established varied greatly, with length of primary VPLs exceeding those of secondary ones in all but one of twenty-three sites receiving both barrier types. Primary VPL lengths across all sites averaged $70 \mathrm{~m}$ and ranged from 16 to $116 \mathrm{~m}$. Secondary VPLs for 23 sites averaged $41 \mathrm{~m}$ and ranged from 14 to $77 \mathrm{~m}$.

\section{Efficacy of Vibratory Plow Treatments}

Between 1998 and 2005, oak wilt was found outside the secondary but inside the primary VPLs (i.e., secondary line failure) for five of eight sites in which both line types were established in 1997 (Table 2). Oak wilt was found outside the primary VPLs (i.e., primary line failure) in one site. For one of these sites where the wilting tree was $3 \mathrm{~m}$ outside a primary line that was $26 \mathrm{~m}$ long, failure of the VPL (in 2003, six years after plowing) was assumed; no secondary lines were installed on this site. Overland spread of the pathogen (in 2002) was cited in 
Table 1. Lengths of vibratory plow lines (VPLs) installed between 1997 and 2005, in 25 park reserve oak wilt sites, Scott Co., MN.

\begin{tabular}{|c|c|c|c|c|}
\hline \multirow{2}{*}{$\begin{array}{l}\text { Site } \\
\text { number }\end{array}$} & \multicolumn{2}{|c|}{ Secondary VPLs } & \multicolumn{2}{|c|}{ Primary VPLs } \\
\hline & yr installed & length $(\mathrm{m})$ & yr installed & length $(\mathrm{m})$ \\
\hline 71 & 1997 & 16 & 1997 & 16 \\
\hline 74 & 1997 & 46 & 1997 & 27 \\
\hline 75 & $\mathrm{n} / \mathrm{a}$ & 0 & 1997 & 39 \\
\hline \multirow[t]{2}{*}{715} & $\mathrm{n} / \mathrm{a}$ & 0 & 1997 & 26 \\
\hline & & & 2003 & unknown \\
\hline 721 & 1997 & 44 & 1997 & 66 \\
\hline 722 & 1997 & 36 & 1997 & 62 \\
\hline \multirow[t]{2}{*}{730} & 1997 & 42 & 1997 & 86 \\
\hline & & & $2002 ; 2003$ & unknown \\
\hline 736 & 1997 & 35 & 1997 & 70 \\
\hline 737 & 1997 & 38 & 1997 & 42 \\
\hline 738 & 1997 & 43 & 1997 & 30 \\
\hline 83 & 1998 & 14 & 1998 & 45 \\
\hline 84 & 1998 & 64 & 1998 & 66 \\
\hline 814 & 1998 & 39 & 1998 & 89 \\
\hline 816 & 1998 & 60 & 1998 & 129 \\
\hline 821 & 1998 & 26 & 1998 & 116 \\
\hline 825 & 1998 & 22 & 1998 & 46 \\
\hline 828 & 1998 & 35 & 1998 & 62 \\
\hline \multirow[t]{2}{*}{829} & 1998 & 32 & 1998 & 62 \\
\hline & & & 2004 & unknown \\
\hline 830 & 1998 & 24 & 1998 & 64 \\
\hline 91 & 1999 & 37 & 1999 & 70 \\
\hline 94 & 1999 & 42 & 1999 & 38 \\
\hline 921 & 1999 & 50 & 1999 & 114 \\
\hline 928 & 1999 & 52 & 1999 & 94 \\
\hline \multirow[t]{2}{*}{934} & 1999 & 51 & 1999 & 84 \\
\hline & & & 2004 & unknown \\
\hline \multirow[t]{2}{*}{945} & 1999 & 77 & 1999 & 126 \\
\hline & & & 2004 & unknown \\
\hline
\end{tabular}

the other case where the wilting tree was $15 \mathrm{~m}$ outside the primary VPL and more than $23 \mathrm{~m}$ from a previously wilted red oak.

Between 1999 and 2005, oak wilt was found outside the secondary but inside the primary lines (i.e., secondary line failure) for six of nine sites where VPLs were established in 1998 (Table 3). Failure of primary lines to stop belowground fungus transmission was found for two of nine sites treated in 1998. Actively wilting trees were found four and six years after VPL installation in the two failed sites. In the former case, one wilting red oak was found within $5.4 \mathrm{~m}$ of the primary VPL. In the latter case, four wilted trees all within $3.6 \mathrm{~m}$ of the primary line were found distributed along $36 \mathrm{~m}$ of the $62 \mathrm{~m}$ of primary VPL.

Between 2000 and 2005, oak wilt was found outside the secondary but inside the primary lines (i.e., secondary line failure) in three of six sites that were plowed in 1999 (Table 4). Failure of the primary VPL (in 2004, five years after plowing) to stop below ground spread was found for one of the six sites. Three wilting red oaks were found within $3.6 \mathrm{~m}$ of the outer side of the primary barrier; the trees were distributed along $4.5 \mathrm{~m}$ of the $84 \mathrm{~m}$ long primary VPL.

\section{Comparison of VPL Placement by Model Type}

The geo-referenced maps and GIS allowed for comparison of how far from the originally infected trees would the primary VPLs have been placed using two confidence levels of the statistical model compared to the actual placement of the installed VPLs (modified French and Stienstra 1978). For slightly more than one-third of the sites, the installer's primary line placement was similar to where they would have been if placed using the $80 \%$ confidence level of the statistical model (example site, Figure 1). For three sites, these modeled VPLs fell inside the installed

Table 2. Observed efficacy of vibratory plow lines (VPLs) for 25 Murphy-Hanrehan Park Reserve sites, Scott Co., MN, $1997-2005$.

\begin{tabular}{|c|c|c|c|c|c|}
\hline \multirow{2}{*}{$\begin{array}{l}\text { Year VPLs } \\
\text { installed }\end{array}$} & \multirow{2}{*}{$\begin{array}{l}\text { Site } \\
\text { number }\end{array}$} & \multicolumn{2}{|c|}{ Secondary VPLs } & \multicolumn{2}{|c|}{ Primary VPLs } \\
\hline & & status-2005 & comment & status-2005 & comment \\
\hline 1997 & 71 & failed & in 2001 & ok & -- \\
\hline 1997 & 74 & failed & in 2001 & ok & -- \\
\hline 1997 & 75 & $\mathrm{n} / \mathrm{a}$ & -- & ok & -- \\
\hline 1997 & 715 & $\mathrm{n} / \mathrm{a}$ & -- & failed & in 2003 \\
\hline 1997 & 721 & ok & -- & ok & -- \\
\hline 1997 & 722 & ok & -- & ok & -- \\
\hline 1997 & 736 & failed & in 2001 & ok & -- \\
\hline 1997 & 737 & failed & in 1999 & ok & -- \\
\hline 1997 & 738 & $\mathrm{ok}$ & -- & ok & -- \\
\hline 1998 & 83 & failed & in 2001 & ok & -- \\
\hline 1998 & 84 & failed & in 1999 & ok & -- \\
\hline 1998 & 814 & failed & in 2001 & ok & -- \\
\hline 1998 & 816 & ok & -- & ok & -- \\
\hline 1998 & 821 & ok & -- & ok & -- \\
\hline 1998 & 828 & ok & -- & ok & -- \\
\hline 1998 & 829 & failed & in 2001 & failed & in 2004 \\
\hline 1998 & 830 & failed & in 2001 & failed & in 2002 \\
\hline 1999 & 91 & failed & 2001 & ok & -- \\
\hline 1999 & 94 & ok & -- & ok & -- \\
\hline 1999 & 921 & ok & -- & ok & -- \\
\hline 1999 & 928 & ok & -- & ok & -- \\
\hline 1999 & 934 & failed & in 2001 & failed & in 2004 \\
\hline 1999 & 945 & failed & in 2003 & ok & -- \\
\hline
\end{tabular}


lines, and fewer oaks would have been retained inside the primary barrier. For the remaining sites, the $80 \%$ confidence level modeled lines encompassed a larger area, and retained more oaks than the installed VPLs (Figure 1). On all 25 sites, the $95 \%$ confidence level modeled lines would have been located farther away from the original diseased trees than were the lines actually established (Figure 1). Lastly, the hypothetical placement of the $95 \%$ confidence level lines were farther out from the original diseased trees than for the $80 \%$ confidence level lines for 20 sites; hypothetical line placement at the two confidence levels were similar for the remaining sites.

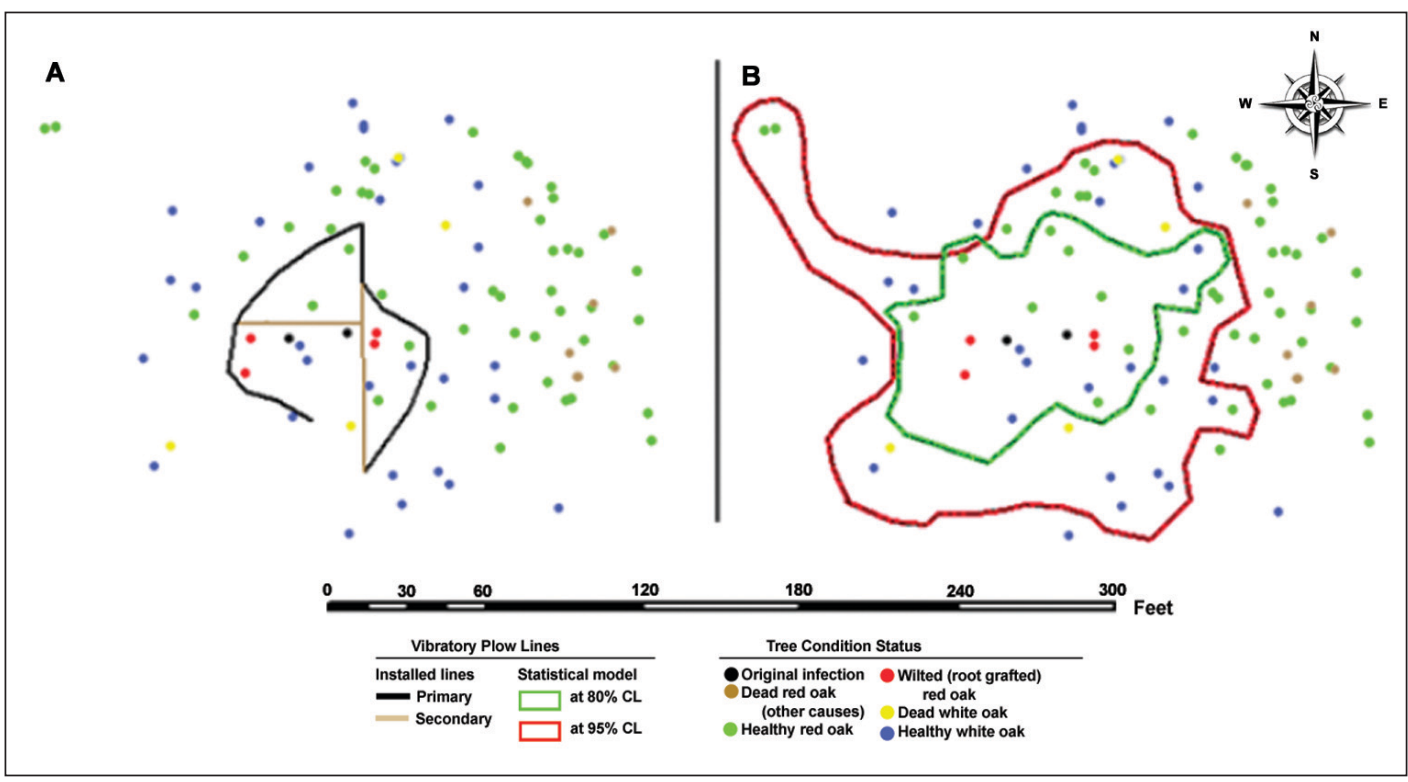

Figure 1. Examples of oak wilt site stem maps showing locations of vibratory plow lines (VPLs) and general health status of oaks in 2001: a) installed VPLs (black = primary; brown = secondary), and b) hypothetical locations of the $80 \%$ and $95 \%$ confidence level (CL) versions of the modeled VPLs (red $=95 \% \mathrm{CL}$ line; green $=80 \% \mathrm{CL}$ line) in relation to the lines actually installed (black $=$ primary; brown = secondary).

\section{Red Oaks Inside Installed and Hypothetical VPLS}

The numbers of red oaks inside the hypothetical and the installed primary VPLs by model type and confidence level were: 465 total, three to eighty-six per site for the $80 \%$ confidence level statistical model; 689 total, five to eighty-six per site for the $95 \%$ confidence level statistical model; and 279, two to twenty-four per site, for the installer's model. For 15 (60\%) sites, the numbers of red oaks were similar (within \pm 5 ) for the experience-guided model and the $80 \%$ confidence level statistical model. For all but one of the remaining sites, the numbers of red oaks were greater for the $80 \%$ confidence level modeled VPLs than the actual installed primary lines. As expected, the more statistically conservative (95\% confidence level) modeled line encompassed more trees (within \pm 5 ) in 23 sites than were encompassed by the installed VPLs. The numbers of trees were similar (within \pm 5 ) for the $95 \%$ confidence level modeled line and the installed VPLs for the remaining two sites. The number of trees inside the $95 \%$ confidence level modeled lines exceeded those inside the $80 \%$ confidence level lines for 18 sites; similar numbers of trees fell within both modeled lines on the remaining sites.

Use of a GIS and the creation of geo-referenced maps also allowed for the theoretical evaluation of numbers of trees that would have been removed inside the installed primary VPLs under different PSPT treatment scenarios. Based on the stem maps, 101 wilted red oaks (from one to eleven per site, including the original infected trees) would have been removed under the "monitor and remove" approach during the time period of the study. In comparison, 279 red oaks (from two to twentyfour per site) would have been removed at the time of plowing if the "cut-to-the-line" approach had been implemented.

Table 3. Hypothetical numbers of red oaks within primary vibratory plow lines (VPLs) to be removed from 25 treated oak wilt sites in the forest park reserve, Scott Co., MN, by treatment option. ${ }^{2}$

\begin{tabular}{|c|c|c|c|c|c|c|c|}
\hline \multirow[t]{2}{*}{ Yr VPLs installed ${ }^{y}$} & \multicolumn{2}{|c|}{ Monitor and remove option ${ }^{\mathrm{x}}$} & \multicolumn{2}{|c|}{ Cut-to-the-line option ${ }^{\mathrm{w}}$} & \multicolumn{3}{|c|}{ Difference in tree numbers by option } \\
\hline & total no. & mean & total no. & mean & total no. & mean & range \\
\hline 1997 & 30 & 3.0 & 91 & 9.1 & 61 & 6.1 & $0-13$ \\
\hline 1998 & 26 & 2.9 & 96 & 10.7 & 70 & 7.8 & $3-18$ \\
\hline 1999 & 13 & 2.2 & 92 & 15.3 & 79 & 13.2 & $4-19$ \\
\hline All years & 69 & 2.8 & 279 & 11.2 & 210 & 8.4 & $0-19$ \\
\hline
\end{tabular}

${ }^{\mathrm{z}}$ Based on analysis of annual site maps in a geographical information system.

${ }^{y}$ Number of sites treated per year: 10, 1997; 9, 1998; and 6, 1999.

${ }^{\mathrm{x}}$ Where red oaks wilting within the primary line between the treatment year and 2005 would have been detected through annual monitoring and removed during the current year.

${ }^{\text {w }}$ Where all red oaks within the primary line would have been removed following treatment, but within the same calendar year of treatment. 
Table 4. Numbers of red oaks inside primary vibratory plow lines (VPLs) installed 1997-1999 compared to numbers inside hypothetical modeled lines at $80 \%$ and $95 \%$ confidence levels (CL) per published mathematical equation. ${ }^{2}$

\begin{tabular}{|c|c|c|c|c|}
\hline $\begin{array}{l}\text { Yr VPLs } \\
\text { installed }\end{array}$ & $\begin{array}{l}\text { Site } \\
\text { number }\end{array}$ & $\begin{array}{l}\text { Inside installed } \\
\text { primary VPLs }\end{array}$ & $\begin{array}{l}\text { Inside modeled } \\
\text { lines } 80 \% \mathrm{CL}\end{array}$ & $\begin{array}{l}\text { Inside modeled } \\
\text { lines } 95 \% \mathrm{CL}\end{array}$ \\
\hline 1997 & 71 & 5 & 5 & 11 \\
\hline 1997 & 74 & 15 & 15 & 21 \\
\hline 1997 & 75 & 2 & 3 & 5 \\
\hline 1997 & 715 & 6 & 13 & 15 \\
\hline 1997 & 721 & 13 & 86 & 86 \\
\hline 1997 & 722 & 12 & 25 & 38 \\
\hline 1997 & 730 & 19 & 39 & 44 \\
\hline 1997 & 736 & 8 & 12 & 25 \\
\hline 1997 & 737 & 9 & 18 & 18 \\
\hline 1997 & 738 & 2 & 12 & 27 \\
\hline 1998 & 83 & 14 & 19 & 21 \\
\hline 1998 & 84 & 10 & 18 & 37 \\
\hline 1998 & 814 & 21 & 15 & 21 \\
\hline 1998 & 816 & 15 & 16 & 22 \\
\hline 1998 & 821 & 3 & 6 & 13 \\
\hline 1998 & 825 & 8 & 21 & 21 \\
\hline 1998 & 828 & 7 & 21 & 42 \\
\hline 1998 & 829 & 11 & 17 & 34 \\
\hline 1998 & 830 & 7 & 7 & 21 \\
\hline 1999 & 91 & 12 & 15 & 23 \\
\hline 1999 & 94 & 4 & 5 & 10 \\
\hline 1999 & 921 & 14 & 12 & 28 \\
\hline 1999 & 928 & 17 & 22 & 47 \\
\hline 1999 & 934 & 21 & 19 & 27 \\
\hline 1999 & 945 & 24 & 24 & 32 \\
\hline All yrs & All sites & 279 & 465 & 689 \\
\hline
\end{tabular}

${ }^{\mathrm{z}}$ Equation published in Bruhn et al. (1991) was used to calculate the required distance from each red oak in each site at each confidence level (CL). The soil factor for the Pemene Soil Series was used.

\section{DISCUSSION}

\section{Belowground Spread Control}

A high level (84\% of infection sites) of local, or belowground, disease control over four to six years was achieved using primary VPLs based on modified use of French and Stienstra's (1978) model installed with a vibratory plow with a $152 \mathrm{~cm}$ long blade. This represents an improvement in control within the park from 1978 to 1982, and from 1997 to 1999 [i.e., where 60\% to 70\% of belowground spread control was documented in 1988 by Sheldstad (unpublished University of Minnesota report; copy on file with USDA Forest Service)]. The suppression of local (i.e., root graft) spread for 118 oak wilt sites treated with a vibratory plow (generally multiple times) as part of the Minnesota Department of Natural Resources coordinated oak wilt suppression program in east central Minnesota was evaluated in a recent study (R. Venette, pers. comm.; unpublished report on file with USDA Forest Service). Overall, $81 \%$ of the sites showed no evidence of spread up to $20.1 \mathrm{~m}$ beyond the primary VPL installed around each infection center within three years of treatment. However, success of the overall oak wilt control effort was related to concurrent use of other treatment tools (i.e., PSPT removal and systemic fungicide injection of red oaks inside the primary lines). Based on evaluation of operational VPL lines established on deep sand soils within the town of Ham Lake,
MN, between 1993 and 1996, primary VPLs were apparently successful in stopping belowground spread of the pathogen on $82 \%$ of 49 treated sites (O'Brien and Mahal, unpublished data).

Secondary VPLs were of limited value in controlling belowground spread within the primary lines. The main value of secondary line use for the park staff is to preserve some of the red oaks within the primary line on the site based on the anecdotal data that only about $50 \%$ of the trees between secondary and primary lines succumb to oak wilt on deep sand soil sites (Juzwik et al. 2004a). Thus, by separating groups of asymptomatic oaks from each other within the primary barriers, additional trees may be saved. Based on this evaluation, between two and seventeen red oaks were preserved on $39 \%$ of the sites where oak wilt was apparently contained within the secondary VPLs (data not shown).

In this study, primary VPLs successfully prevented belowground spread of the oak wilt fungus on more than $80 \%$ of 25 sites for at least four to six years. Several explanations are offered for why failures occurred. Primary VPLs may have been placed too close to the original infections and the fungus may have already moved beyond the point of root severing at the time of plowing. Alternative VPL line placement models can be considered as a possible improvement for future treatments. Site and machine limitations may also result in insufficient depth of root severing. Buried boulders may prevent full insertion of the plow blade at one or more points along designated plow lines. Hard soil conditions due to drought may also limit blade insertion and require more machine power and traction to overcome. As of the year 2000 , only a tracked cable plow has been used by the park district due to its superior traction. Theoretically, it is possible that new root connections may have formed across the zone of severed roots several years after plow treatment. No evidence exists, however, for the occurrence of re-grafting across either a VPL or, in other states, across a filled-in trench following root disruption by a trenching machine. The occurrence and frequency of new grafts forming across primary VPLs, the length of time for such grafts to form, and the abundance of new root proliferation for $Q$. rubra and $Q$. ellipsoidalis following root severing should be considered in future studies, particularly in Michigan, Minnesota, and Wisconsin, where vibratory plows are used in oak wilt control efforts. Lastly, local aboveground spread of the fungus may have occurred via pathogen-contaminated nitidulid beetles. A high percentage (75\%) of such contaminated beetles visiting fresh wounds (artificially created) on healthy trees inside primary VPLs in the same park reserve was documented previously (Juzwik et al. 2004b). The frequency of local pathogen spread by insects is higher than frequency of longer distance spread (Menges and Loucks 1984). Improvement of the park reserve's oak wilt control program could logically be accomplished through removal of PSPTs.

\section{Options for Aboveground Spread Control}

Spatial analysis using the geo-referenced maps allowed hypothetical consideration of two options for reducing probability of aboveground fungus spread. In particular, estimates of numbers of red oaks that would have been removed under each option were obtained. Such data is valuable when determining which option is most consistent with the park's oak wilt management objectives and for cost comparisons. As expected, a much larger number of red oaks would have been removed under a "cut-tothe-line" approach than under a "monitor and remove" option 
(i.e., a 300\% increase overall). Estimates of removal costs under both scenarios were not addressed in this study; however, both options were deemed economically feasible in a general sense. Based on results of this study and other considerations, the park reserve staff has selected the "monitor and remove" option.

\section{Alternative VPL Placement Models}

Spatial analysis using the geo-referenced maps also allowed for theoretical comparison of how VPL placement differs with the lines placed by park staff in this study and how potential red oak loss (either through disease or PSPT removal) could vary by line placement model used. On all sites but one, primary lines placed using the 95\% confidence level of the statistical model were located at a greater distance from the original diseased oaks than were the installed lines. The theoretical placement of lines according to the $80 \%$ confidence level of the same model was similar to that of the installed lines on approximately one-third of the sites while the modeled lines for half of the sites were farther out, distance-wise, than the installed lines. The $95 \%$ and $99 \%$ confidence level versions of the statistical model are recommended for VPL placement by university extension and natural resource agencies in Michigan (Bruhn and Heyd 1992; Adams and Blankenheim 2001), and Wisconsin (Carlson and Martin 2005).

Oak wilt eradication in the affected stands and one time treatment are the goals for many of the sites for which the model is used in Wisconsin (Kyoko Scanlon, pers. comm.). Thus, conservative VPL line placement coupled with "cut-to-the-line" red oak removal is a logical approach to achieve such goals. In hypothetical spatial analysis for Murphy-Hanrehan Park, a "cut-to-the-line" option coupled with primary VPLs placed according to the $95 \%$ confidence level statistical model represented a $250 \%$ increase in numbers of red oaks that, theoretically, would have been removed. In contrast, the line placement model currently used by the park reserve represents a trade-off between trying to preserve as many oaks as possible while trying to minimize oak losses over time due to oak wilt. In essence, the park's staff have chosen to manage the disease versus eradicate it from their forest lands. Consistent with that approach, the park has now adopted a "monitor and remove" option for reducing the potential for overland spread of the pathogen within the park reserve and has chosen to continue using their modified version of French and Stienstra's model (1978).

One other point arose during the theoretical comparison of VPL placement models. The confidence levels of the statistical model examined are based on the inter-tree distance associated with selected probabilities (e.g., 95\%) that a tree will not contract oak wilt through root grafts from an inoculum source tree for one year following its death for the Pemene soil series (Bruhn et al. 1991). The use of the published statistical models (Bruhn et al. 1991) for controlling oak wilt in stands on soil types other than the Pemene and Grayling series could result in unnecessary loss of trees (Bruhn and Heyd 1992). The rate at which the oak wilt fungus moves belowground varies greatly by soil type and topography, as well as other factors (Juzwik 2009). Therefore, the hypothetical use of the statistical model developed for the Pemene soil series in the study may have placed the VPLs farther out than necessary for the soil type characteristic of Murphy-Hanrehan Park. Indeed, extensions of the statistical model need to be developed for other common soil types where the model is used (Bruhn and Heyd 1992).

\section{CONCLUSIONS}

For the management forester of the Murphy-Hanrehan Park Reserve, overall oak wilt treatment and program success is measured by 1) the total number of trees saved at the infection center level and across the landscape, 2) the numbers of infection centers contained by effective VPLs, and 3) the numbers of new centers initiated by insect spread. For the park, the most parsimonious strategy for controlling belowground fungus spread is to place the barrier such that the fewest numbers of oaks are left within the primary VPL, without excessive risk that the pathogen is already in the root systems of trees outside the primary plow line. Based in part on an analysis of the present study, the park's forestry division plans to continue using their modified version of the French and Stienstra (1978) model for placing VPLs. Re-treatment of sites with the vibratory plow is feasible and considered worth the effort to save additional trees when the disease continues to be quite active several years after the initial plowing or a when a "breakout" results from unintentional under-placement of the original primary VPLs.

Diligent annual removal of recently wilted red oaks inside the primary barriers would reduce incidence of new pathogen introductions (i.e., new infection centers), affording even greater control in the reserve's oak wilt management program. The park reserve was able to fully implement the "monitor and remove" sanitation option in 2008 in the hopes of increasing program effectiveness.

Acknowledgments. Funding for stem map data collection and mapping was provided by the Minnesota Environment and Natural Resources Trust Fund as recommended by the Legislative Commission on Minnesota Resources and from the Special Technology Development Program of the US Forest Service. Special thanks to R.L. Heyd, K. Scanlon, and A.D. Wilson for review and helpful discussion of an earlier version of the manuscript. The authors also thank G. Watson and two anonymous individuals for their review and helpful suggestions of the submitted manuscript. The technical assistance of Shawn Neuman and Stacey Olszewski is gratefully acknowledged.

\section{LITERATURE CITED}

Adams, G., and Z. Blankenheim. 2001. Oak wilt in Michigan. MSU Extension Bulletin EZ764, Michigan State Univ., E. Lansing, MI. 8 p.

Billings, R.E. 2000. State forest health programs: a survey of state foresters. Journal of Forestry 98:20-25.

Bruhn, J.N., and R.L. Heyd. 1992. Biology and control of oak wilt in Michigan red oak stands. Northern Journal of Applied Forestry 9:47-51.

Bruhn, J.N., J.B. Pickens, and D.B. Stanfield. 1991. Probit analysis of oak wilt transmission through root grafts in red oak stands. Forest Science 37:28-44.

Carlson, J.C., and A.J. Martin. 2005. Oak wilt management - what are the options? University of Wisconsin Extension Publication. G3590. 6 pp.

Cook, S.J. 2001. Current practices and suppression methods for managing oak wilt disease. pp. 93-100. In: C. Ash (ed.), Shade Tree Wilt Diseases, APS Press, American Phytopathological Society, St. Paul, MN.

French, D.W., and W.C. Stienstra. 1978. Oak wilt. Univ. of Minn., Agriculture Expt. Sta., Extension Folder 310. 6 pp.

Haight, R.G., S.V. Mehta, T. Hovie, D.J. Smith, R.C. Venette, F.R. Homans, and A.J. Walter. 2009. An economic impact assessment for oak wilt in Anoka County, Minnesota. p. 31. In: K. McManus and K.W. Gottschalk (eds.), Proceedings of the 20th U.S. Department of 
Agriculture Interagency Research Forum on Gypsy Moth and Other Invasive Species, January 13-16, 2009, Annapolis, MD. USDA Forest Service, Gen. Tech. Rep. NRS-P-51.

Juzwik, J. 2009. Epidemiology and occurrence of oak wilt in Midwestern, Middle, and South Atlantic states. pp. 49-60. In: R.F. Billings and D.N. Appel (eds.), Proceedings of the National Oak Wilt Symposium, June 4-7, 2007, Austin, TX. Texas Forest Service Publication 166.

Juzwik, J., S.J. Cook, L.M. Haugen, and J. Elwell. 2004a. Oak Wilt: People and Trees, A Community Approach to Management. CDROM version 2004 v 1.3. USDA Forest Service, North Central Research Station. St. Paul, MN.

Juzwik, J., T.C. Skalbeck, and M.F. Neuman. 2004b. Sap beetle species (Coleoptera: Nitidulidae) visiting fresh wounds on healthy oaks during spring in Minnesota. Forest Science 50:757-764.

Keys, Jr., J., C. Carpenter, S. Hooks, F. Koenig, W.H. McNabb, W. Russell, and M.L. Smith. 1995. Ecological Units of the Eastern United States First approximation. USDA Forest Service Tech. Publ., R8-21.

Menges, E.S., and O.R. Loucks. 1984. Modeling a disease-caused patch disturbance: oak wilt in the Midwestern United States. Ecology 65:487-498.

Minnesota Department of Natural Resources. 2006. Ecological Subsections of Minnesota. Accessed 01/2010. <http://www.dnr.state.mn.us/ ecs/index.html>

USDA Natural Resources Conservation Service. 2007. Map unit description (Brief, Generated), Scott County, Survey Area Version 4.

USDA Forest Service Northeastern Area State and Private Forestry. 2009. Northeastern Area participation guidelines for oak wilt cooperative prevention and suppression projects. U.S. Forest Service, New Town Square, PA. CD-Rom (December 2008 version).

\section{Jennifer Juzwik (corresponding author) \\ U.S. Forest Service \\ Northern Research Station \\ 1561 Lindig St. \\ St. Paul, MN 55108, U.S.}

\section{Joseph O'Brien}

U.S. Forest Service

Northeastern Area State and Private Forestry

1992 Folwell Ave.

St. Paul, MN 55108, U.S.

Charles Evenson

Three Rivers Park District

12615 County Rd. 9

Plymouth, MN 55441, U.S

\section{Paul Castillo}

U.S. Forest Service

Northern Research Station

1561 Lindig St.

St. Paul, MN 55108, U.S.

Graham Mahal

6108 Oakwood Ln

Circle Pines, MN 55014, U.S.
Résumé. L'efficacité des mesures de contrôle de la flétrissure du chêne qui ont été prises entre 1997 et 1999 ont été évaluées dans une réserve forestière d'un parc urbain du Minnesota aux États-Unis. Un taux élevé de succès ( $84 \%$ des centres d'évaluation de maladie) a été atteint en contrôlant dans le sol la dissémination de la maladie vasculaire durant quatre à six ans, et ce en brisant mécaniquement la connexion inter-racinaire au moyen d'une lame sur une charrue à câble. La localisation des lignes de coupes primaires a été basée sur un modèle modifié de règle du pouce. Des scénarios plausibles basés sur deux protocoles de prévention de la production de spores, et donc de ce fait d'une dissémination au-dessus du sol par les insectes, ont été explorés conjointement avec des modèles alternatifs de traitement des racines au moyen d'un système d'information géographique. Avec un modèle d'intervalle statistique de confiance de $95 \%$, le nombre de chênes rouges à l'intérieur des lignes préliminaires était de 2,5 fois supérieur à celui des chênes à l'intérieur des lignes primaires de coupes installées et il représentait la différence de perte en arbres si tous les chênes rouges étaient enlevés jusqu'aux lignes primaires (i.e. à la ligne de coupe du protocole). Alternativement, l'option du «suivi et enlèvement» des arbres infectés (i.e. l'abattage annuel des chênes infectés) aurait donné un abattage de $64 \%$ moindre par rapport au protocole décrit initialement. La division des parcs forestiers a subséquemment ajouté le protocole décrit à son programme de contrôle de la flétrissure du chêne.

Zusammenfassung. Wir haben die Effektivität der Kontrollmaßnahmen gegen die Eichenwelke in den Jahren von 1997 bis 1999 in einem Stadtpark in Minnesota bewertet. Es wurde ein hoher Erfolgsgrad (84 $\%$ der bewerteten Krankheitszentren) bei der Ausbreitung des vaskuären Pathogens über einen Zeitraum von vier bis sechs Jahren durch den Einsatz eines Vibrationspfluges und der mechanischen Trennung der Wurzelverbindungen erreicht. Die Plazierung der äussersten Behandlungslinien wurde über den Daumen geschätzt. Plausible Szenarien basierten auf zwei Protokollen für die Prävention der Sporenproduktion des Erregers und oberhalbdes Bodens anhand der Insektenverteilung. Das wurde verglichen mit einem alternativen System der Wurzelbehandlung, welches auf einem geographischen Informationsdienst (GIS) beruht. Für $95 \%$ Sicherheit in einem statistischen Modell war die Anzahl der Roteichen innerhalb der Linien 2,5 mal höher und repräsntierten die Differenz in Baumverlusten, wenn alle Roteichen bis zu den primären Linien (CTL) entfernt wurden. Alternativ würde eine Option zur Überwchung und Entfernung (MR, z.B. jährliche Entfernung von befallenen Bäumen) zu $64 \%$ weniger Fällungen führen als CTL. Die Forstbehörde hat das MRProtokoll subsequenterweise in sein Eichenwelken-Kontrollprogramm aufgenommen.

Resumen. Fueron evaluadas la efectividad de las acciones para controlar el marchitamiento del encino entre 1997 y 1999 para la reserva de un parque forestal urbano en Minnesota, U.S. Se logró un alto nivel de éxito ( $84 \%$ de centros de enfermedad evaluados) en el control de la dispersión subterránea del patógeno vascular para cuatro a seis años por disrupción mecánica de las conexiones entre raíces de los árboles con la cuchilla de una máquina articulada (VP). La ubicación de los tratamientos (líneas primarias) estuvo basada en un modelo modificado. Se exploraron los escenarios con base en dos protocolos para prevención de la producción de esporas por el patógeno, y la dispersión de los insectos, en conjunción con la alternativa de modelos de tratamiento de la raíz usando un sistema de información geográfica. Para un modelo estadístico con un 95 de nivel de confianza, el número de encinos rojos dentro de las líneas primarias fueron 2.5 veces mayores que los instalados en las demás líneas y representan las diferencias en las pérdidas de árboles si todos los encinos rojos fuesen removidos a las líneas primarias (CTL). Alternativamente, una opción "monitor y remoción" (MR) (remoción anual de los encinos marchitos), podría tener resultados en $64 \%$ que las remociones en CTL. La división forestal de parques subsecuentemente añadió el protocolo MR a su programa de encinos marchitos. 